\title{
SYNTHESIS AND CHARACTERIZATION OF GADOLINIUM-BASED NANOCRYSTALS FOR THEIR POTENTIAL APPLICATION AS TRIMODAL IMAGING CONTRAST AGENTS
}

\author{
HAROON UR RASHID ${ }^{a}$, MUHAMMAD YASEEN $^{b}$, ALI RIAZ $^{a^{*}}$, KAMIN KHAN $^{a}$, HANIF UR RAHMAN $^{a}$, \\ KHALID KHAN ${ }^{c}$, NASIR AHMAD ${ }^{c}$ AND MARCO ANTONIO UTRERA MARTINES ${ }^{d^{*}}$
}

\author{
${ }^{a}$ Department of Chemistry, Sarhad University of Science \& Information Technology, Peshawar, Khyber Pakhtunkhwa, Pakistan. \\ ${ }^{b}$ Institute of Chemical Sciences, University of Peshawar, Peshawar, Khyber Pakhtunkhwa, Pakistan. \\ ${ }^{c}$ Department of Chemistry, Islamia College University, Peshawar, Khyber Pakhtunkhwa, Pakistan. \\ ${ }^{d}$ Institute of Chemistry, Federal University of Mato Grosso do Sul, Campo Grande, MS, Brazil.
}

\begin{abstract}
Lanthanide-doped gadolinium nanomaterials have attracted considerable attention due to their promising applications in biological imaging. Sodium gadolinium fluoride $\left(\beta-\mathrm{NaGdF}_{4}\right)$ nanomaterials act as perfect host for doping of luminescent lanthanide ions. Due to heavy nature of gadolinium, it can strongly absorb X-ray radiations. Therefore, Gd-based nanomaterials are applied as contrast agents for X-ray tomography (CT). Presence of seven unpaired electrons in $\mathrm{Gd}^{+3}$ ion, its large magnetic moment and long electronic relaxation time makes it an ideal candidate to enhance water proton relaxation rates. These characteristics make Gd-based nanomaterial useful for their potential application as MRI contrast agents. In this work, sodium gadolinium fluoride is doped with ytterbium and erbium to produce $\beta-\mathrm{NaGdF}_{4}: \mathrm{Yb} / \mathrm{Er}$ as core nanocrystals. They are subsequently coated with sodium gadolinium fluoride doped with neodymium $\left(\beta-\mathrm{NaGdF}_{4}: \mathrm{Nd}\right)$ to produce $\beta$ $\mathrm{NaGdF}_{4}: \mathrm{Yb} / \mathrm{Er} @ \beta-\mathrm{NaGdF}_{4}: \mathrm{Nd}$ core-shell nanocrystals. Powder X-ray diffraction (XRD) results indicated that $\beta$-NaGdF 4 (host), $\beta$-NaGdF 4 : $\mathrm{Yb} / \mathrm{Er}(\mathrm{core})$ and $\beta$ $\mathrm{NaGdF}_{4}: \mathrm{Yb} / \mathrm{Er} @ \beta$ - $\mathrm{NaGdF}_{4}: \mathrm{Nd}$ (core-shell) nanocrystals all exist in hexagonal crystalline phase. While Dynamic Light Scattering (DLS) results indicated that the particle size of the synthesized nanocrystals was in range of 12 to $27 \mathrm{~nm}$. FTIR results confirmed that the synthesized nanocrystals were stabilized by oleic acid. Nanocrystals reported in this work are expected to be useful trimodal contrast agents for photoluminescence, X-ray tomography and Magnetic Resonance Imaging (MRI).
\end{abstract}

Keywords: lanthanide, nanocrystals, trimodal, gadolinium, contrast agents.

\section{INTRODUCTION}

Recently, rapid research developments in the field of medicine and life science have also driven the biomedical research. This emerging and growing research field comprises of a number of bioassay approaches such as X-ray Computed Tomography (also called Computed Tomography, CT), Single-Photon Emission Computed Tomography (SPECT) [1-4], Positron Emission Tomography (PET) [5, 6] and Magnetic Resonance Imaging (MRI) [7-9]. These tomographic imaging methods have high penetration power. Therefore, they play a key role in biomedical imaging. However, these techniques have some unavoidable drawbacks such as limited spatial resolution, long scan acquisition time and application of strong ionizing radiations (except for MRI) [10-13]. Furthermore, these modalities differ from each other in spatial and temporal resolution, imaging depths, anatomical and molecular details and the necessary material properties of contrast agents essential to improve the quality of images in terms of their visibility. In many cases, it is beneficial to use several complimentary imaging techniques for rapid and precise diagnosis. Since majority of these imaging modalities apply exogenous contrast agents to improve the signal-tonoise ratio, therefore, the development of multimodal contrast agents is highly desirable to obtain images of better quality. Such agents have proved more useful for patient care.

Moreover, they also reduce the cost and increase the safety by restricting the number of contrast agents administration needed for imaging purposes [14]. The idea of designing multimodal contrast agents provides the prospective to integrate the benefits of different modalities while at the same time overcoming the shortcomings of one another $[15,16]$. In addition, multimodal contrast agents can be very useful for the technical development of emerging imaging techniques [17-19]. Current research indicate that nanomaterial-based multimodal imaging probes have been developed for accurate imaging and diagnosis while applying different imaging modalities Recently, lanthanide metal ions doped with upconverting (Excitation at lower energy than emission) nanomaterial have been investigated for their potential applications in biomedical imaging. Such nanomaterials possess high photostability and show neither photobleaching nor photoblinking [20]. Additionally, upconverting nanomaterials are excited by near-infrared (NIR) radiations which ensure optical imaging of deeper tissues with significantly controlled autofluorescence, and create enhanced image contrast [21-23]. $\beta-\mathrm{NaGdF}_{4}$ host nanomaterial doped with lanthanide ions combination of $\mathrm{Yb}^{3+}, \mathrm{Er}^{3+}$ or $\mathrm{Yb}^{3+}, \mathrm{Tm}^{3+}$ have exhibited significant upconversion luminescence [24]. Gadolinium is a heavy metal of high atomic number which strongly absorbs X-rays. Its trivalent ion $\left(\mathrm{Gd}^{3+}\right)$ causes enhancement of water proton relaxation rate due to maximum number (seven) of unpaired electrons (among all lanthanide ions), a long electronic relaxation time $\left(\sim 10^{-9} \mathrm{~s}\right)$ and a large magnetic moment (7.9 BM). These properties make Gadolinium the best candidate for applications as luminescence, CT and MRI contrast agents [11, 25, 26]. Upconverting nanomaterial based multimodal contrast agents can serve for fluorescence imaging, CT and MRI modalities. Such contrast agents possess the advantages of high sensitivity (fluorescence imaging) as well as the potential of high spatial resolution imaging (of MRI and CT techniques) [27]. This work reports the synthesis of $\beta-\mathrm{NaGdF}_{4}$ nanocrystals doped with $\mathrm{Yb}^{3+}$ and $\mathrm{Er}^{3+}$ $\left(\mathrm{NaGDF}_{4}: \mathrm{Yb} / \mathrm{Er}\right)$. They were synthesized as core nanocrystals and were subsequently coated with a shell of $\mathrm{NaGdF}_{4}: \mathrm{Nd}^{3+}$ (Core-shell nanocrystals).

\section{EXPERIMENTAL}

Chemicals: Gadolinium Oxide (99.9\%), Ytterbium(III) acetate hydrate (99.99\%), Erbium Oxide (99.9\%), Neodymium(III) acetate hydrate (99.9\%), Sodium hydroxide ( $\geq 97 \%$ ), 1-octadecene (90\%), oleic acid (90\%), Ammonium fluoride $(\geq 99.9 \%)$, Acetic Acid glacial $(\geq 99.85 \%)$ and cyclohexane were purchased from Sigma-Aldrich. All chemicals were used without any further purification.

\section{Synthesis of Gadolinium acetate hydrate}

Gadolinium acetate hydrate was prepared following the procedure reported by Dühnen and Haase for the synthesis of gadolinium trifluoroacetate (Gd-TFA) [28]. $\mathrm{Gd}_{2} \mathrm{O}_{3}(3.63 \mathrm{~g}, 10 \mathrm{mmol})$ was added to a solution of $80 \mathrm{mmol}$ of concentrated acetic acid $(4.6 \mathrm{~mL})$ and $12.4 \mathrm{~mL}$ of distilled water. The solution was heated under reflux (at ca. $90{ }^{\circ} \mathrm{C}$ ) for $60 \mathrm{~min}$ to dissolve the $\mathrm{Gd}_{2} \mathrm{O}_{3}$ completely. After removing excess acetic acid and water with a rotary evaporator at $50{ }^{\circ} \mathrm{C}$, Gadolinium acetate hydrate was obtained as a white powder. Subsequently the powder was dried at $60^{\circ} \mathrm{C}$ for $17 \mathrm{~h}$. 


\section{Synthesis of Erbium acetate tetra hydrate}

Erbium acetate tetra hydrate was prepared according to the procedure reported by Mondry and Bukietyńska [29]. $\mathrm{Er}_{2} \mathrm{O}_{3}$ was dissolved in concentrated acetic acid and alkalized to $\mathrm{pH}=4$ using deionized water. The well-shaped crystals of Erbium acetate tetra hydrate were formed during very slow evaporation.

\section{Synthesis of $\beta$ - $\mathrm{NaGdF}_{4}$ nanocrystals}

$\beta$ - $\mathrm{NaGdF}_{4}$ nanocrystals were synthesized according to the procedure reported by Tian and his coworkers with a slight modification [30]. Gadolinium acetate hydrate $(0.4 \mathrm{mmol})$ was added to a $50-\mathrm{mL}$ three-neck round-bottom containing oleic acid $(4 \mathrm{~mL})$ and 1 -octadecene $(6 \mathrm{~mL})$. The mixture was heated to $150{ }^{\circ} \mathrm{C}$ for $1 \mathrm{~h}$ under nitrogen atmosphere. It was then allowed to cool down to $50{ }^{\circ} \mathrm{C}$. After that, a methanol solution $(5.4 \mathrm{~mL})$ of $\mathrm{NH}_{4} \mathrm{~F}(1.36 \mathrm{mmol})$ and $\mathrm{NaOH}(1$ mmol) was added and stirred at $50{ }^{\circ} \mathrm{C}$ for $30 \mathrm{~min}$ under nitrogen atmosphere. To remove the methanol, the reaction mixture was heated at $100{ }^{\circ} \mathrm{C}$ for $30 \mathrm{~min}$ in vacuum. Subsequently, the temperature was raised to $290^{\circ} \mathrm{C}$ and maintained for $1.5 \mathrm{~h}$ under $\mathrm{N}_{2}$ atmosphere with continuous magnetic stirring. The solution was then allowed to cool to room temperature. The nanocrystals were precipitated by the addition of ethanol and isolated via centrifugation. The as-precipitated nanocrystals were washed several times with ethanol and dried in air at $70{ }^{\circ} \mathrm{C}$ overnight. The nanocrystals were collected and dispersed in $4 \mathrm{~mL}$ of cyclohexane for further characterization.

\section{Synthesis of $\beta$ - $\mathrm{NaGdF}_{4}: \mathrm{Yb} / \mathrm{Er}$ core nanocrystals}

The lanthanide-doped $\mathrm{NaGdF}_{4}$ core and core-shell nanocrystals were synthesized by a thermal decomposition method as described by Zheng et al. [31] with slight modification. In a typical procedure, $0.4 \mathrm{mmol}$ of $\mathrm{Gd}\left(\mathrm{CH}_{3} \mathrm{COO}\right)_{3} \cdot \mathrm{H}_{2} \mathrm{O}, 0.392 \mathrm{mmol}$ of $\mathrm{Yb}\left(\mathrm{CH}_{3} \mathrm{COO}\right)_{3} \cdot 4 \mathrm{H}_{2} \mathrm{O}$ and $0.008 \mathrm{mmol}$ of $\mathrm{Er}\left(\mathrm{CH}_{3} \mathrm{COO}\right)_{3} \cdot 4 \mathrm{H}_{2} \mathrm{O}$ were mixed with $8 \mathrm{~mL}$ of oleic acid $(\mathrm{OA})$ and $12 \mathrm{~mL}$ of 1 octadecene in a $50 \mathrm{~mL}$ three-neck round-bottom flask. The mixture was then heated to $150{ }^{\circ} \mathrm{C}$ and kept there for $60 \mathrm{~min}$ in the presence of continuous $\mathrm{N}_{2}$ flow and magnetic stirring, resulting in a clear yellowish-brown solution. After cooling the solution to room temperature, $10 \mathrm{~mL}$ of methanol solution containing $2.72 \mathrm{mmol} \mathrm{NH}_{4} \mathrm{~F}$ and $2 \mathrm{mmol} \mathrm{NaOH}$ was added and the solution was stirred again at $50{ }^{\circ} \mathrm{C}$ for $30 \mathrm{~min}$ to remove methanol. Thereafter, the solution was heated to $290{ }^{\circ} \mathrm{C}$ and maintained for $90 \mathrm{~min}$. After cooling down to room temperature, the nanocrystals were precipitated by addition of ethanol, and collected by centrifugation. They were washed with ethanol several times, and finally re-dispersed in cyclohexane.

\section{Synthesis of $\beta$ - $\mathrm{NaGdF}_{4}: \mathrm{Yb} / \mathrm{Er} @ \beta-\mathrm{NaGdF}_{4}: \mathrm{Nd}$ core-shell nanocrystals}

For shell growth $\left(\beta-\mathrm{NaGdF}_{4}: \mathrm{Nd}\right), 0.788 \mathrm{mmol}$ of $\mathrm{Gd}\left(\mathrm{CH}_{3} \mathrm{COO}\right)_{3} \cdot \mathrm{H}_{2} \mathrm{O}$ and $0.012 \mathrm{mmol}$ of $\mathrm{Nd}\left(\mathrm{CH}_{3} \mathrm{COO}\right)_{3} \cdot \mathrm{H}_{2} \mathrm{O}$ were added to a $50 \mathrm{~mL}$ three-neck roundbottom flask containing $8 \mathrm{~mL}$ of $\mathrm{OA}$ and $12 \mathrm{~mL}$ of 1 -octadecene and heated to $150{ }^{\circ} \mathrm{C}$ under $\mathrm{N}_{2}$ flow and magnetic stirring for $60 \mathrm{~min}$; likewise a clear yellowish-brown solution was developed. After cooling down to $80^{\circ} \mathrm{C}, 0.4 \mathrm{mmol}$ $\beta$ - $\mathrm{NaGdF}_{4}: \mathrm{Yb} / \mathrm{Er}$ nanocrystal seeds (core) in $6 \mathrm{~mL}$ of cyclohexane was added to the above solution. After complete evaporation of cyclohexane, $10 \mathrm{~mL}$ methanol solution containing $2.72 \mathrm{mmol} \mathrm{NH}_{4} \mathrm{~F}$ and $2 \mathrm{mmol} \mathrm{NaOH}$ was added. The mixture was then stirred at $50{ }^{\circ} \mathrm{C}$ for $30 \mathrm{~min}$. In a similar fashion, after the evaporation of methanol the solution temperature was raised to $290{ }^{\circ} \mathrm{C}$ and maintained for 90 min under $\mathrm{N}_{2}$ flow with vigorous stirring. The core-shell nanocrystals were obtained finally at room temperature with the same method as described above.

\section{RESULTS AND DISCUSSION}

All nanocrystals were characterized by Dynamic light scattering (DLS), X-ray Diffractometery (XRD) and Infrared (IR) analyses. DLS measurements were performed with a Zeta sizer Nano-Zs (Malvern, UK) at room temperature. The crystal structure of as-synthesized UCNPs was analyzed using D2 phase XRD (Bruker, Germany) equipped with PW3020 goniometer (Theta/2theta), 3kW generator ( $\mathrm{Cu}$ anode), Nickel filter and operated using $\mathrm{K}$-alpha1 (=1.54 $\mathrm{A})$.

\section{Dynamic Light scattering Study}

The results of host $\left(\beta-\mathrm{NaGdF}_{4}\right)$, core $\left(\beta-\mathrm{NaGdF}_{4}: \mathrm{Yb} / \mathrm{Er}\right)$ and core-shell $(\beta$ $\left.\mathrm{NaGdF}_{4}: \mathrm{Yb} / \mathrm{Er} @ \beta-\mathrm{NaGdF}_{4}: \mathrm{Nd}\right)$ nanocrystals confirmed their size to be 19.69 $\mathrm{nm}, 12.35 \mathrm{~nm}$ and $26.62 \mathrm{~nm}$ respectively (Fig. 1-3).

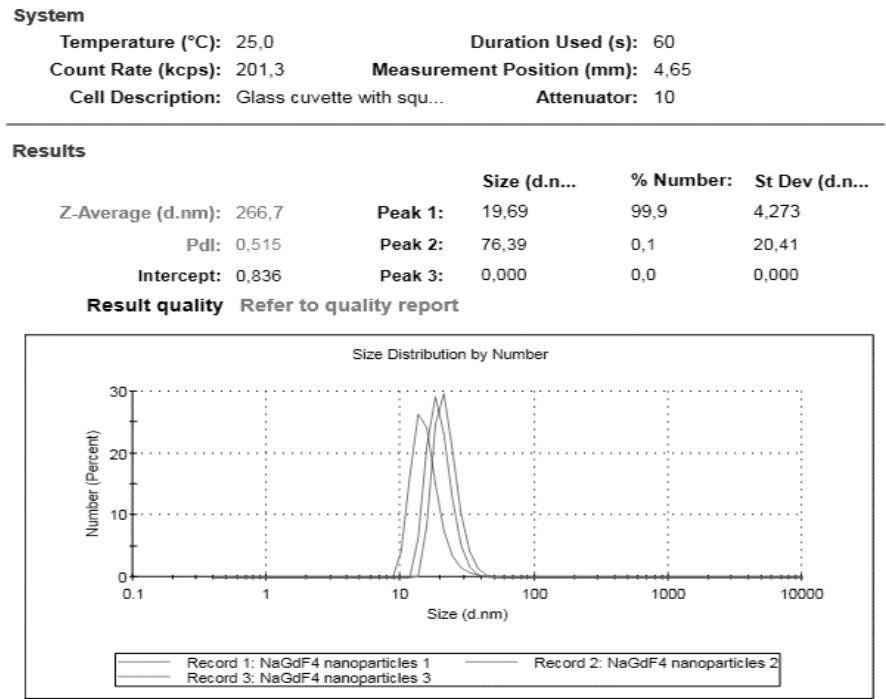

Figure 1. Dynamic Light Scattering Measurement (DLS) of Host $\left(\beta-\mathrm{NaGdF}_{4}\right)$, (Number vs Size).

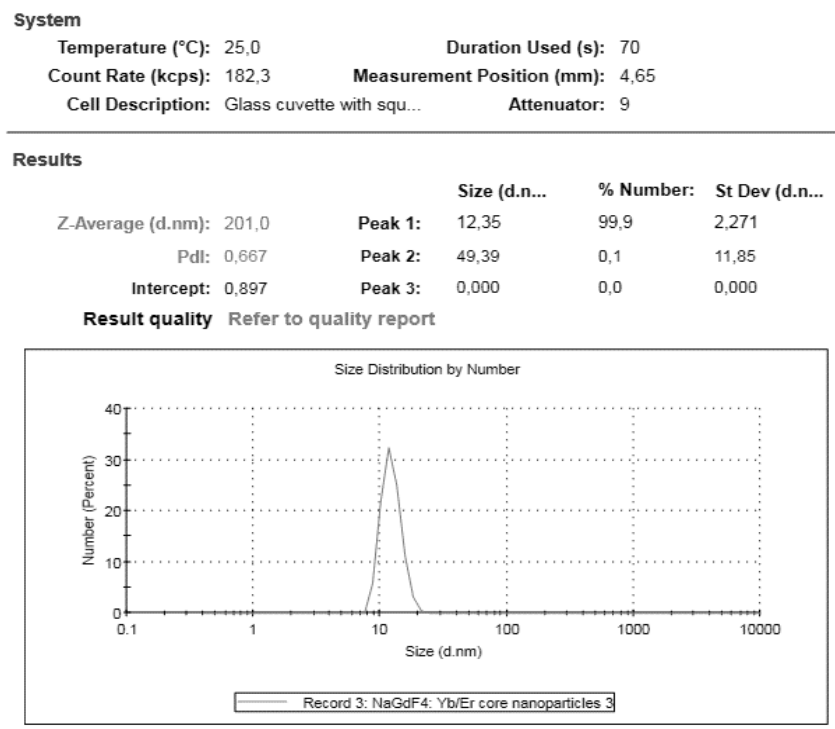

Figure 2. Dynamic Light Scattering Measurement (DLS) of core $\left(\mathrm{NaGdF}_{4}: \mathrm{Yb} / \mathrm{Er}\right)$, (Number vs Size).

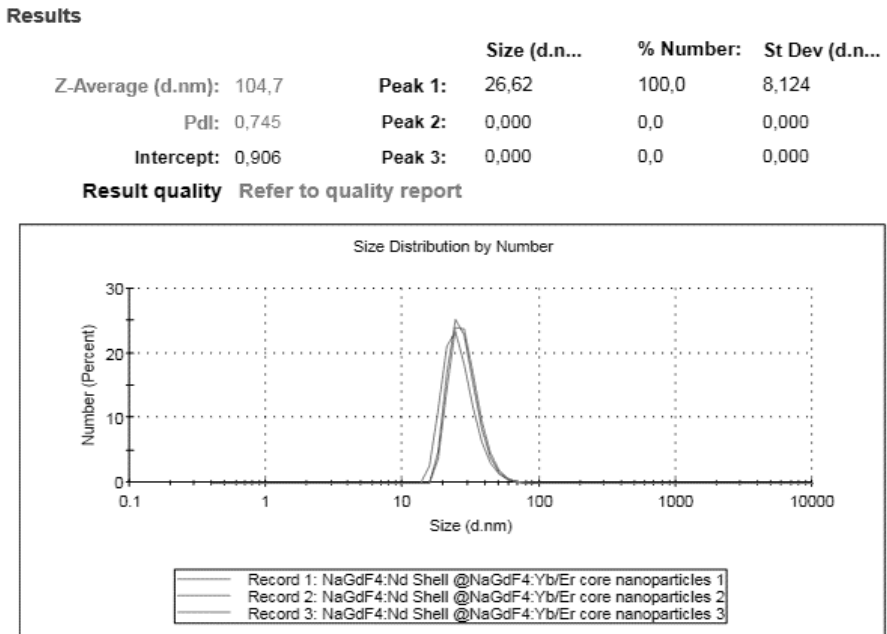

Figure 3. Dynamic Light Scattering Measurement (DLS) of $\beta$ NaGdF4:Yb/Er@ $\beta$-NaGdF4:Nd core-shell nanocrystals (Number vs Size). 


\section{XRD Study}

The X-ray diffraction spectrum of the host $\beta-\mathrm{NaGdF}_{4}$ nanocrystals is given in fig. 4. It shows well defined peaks. The $\mathrm{X}$-ray diffraction reveals that the synthesized sample $\beta$ - $\mathrm{NaGdF}_{4}$ has some regular patterns which are due to the presence of $\beta-\mathrm{NaGdF}_{4}$ crystals. The spectral lines present in the $\beta-\mathrm{NaGdF}_{4}$ are summarized in Table. Values in Table are generated in Origin ${ }^{\circledR} 8.0$, whereas thickness " $\mathrm{t}$ " and "d-spacing" of diffraction peaks are calculated using MS-Excel 2007.

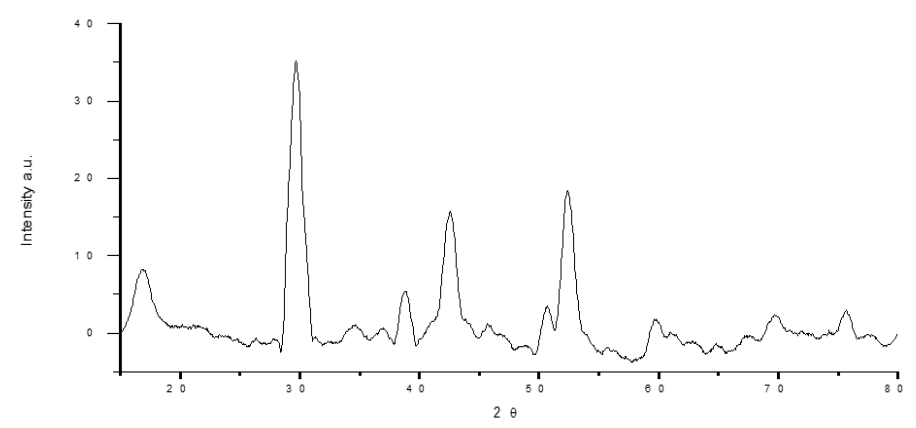

Figure 4. XRD pattern of $\beta-\mathrm{NaGdF}_{4}$ nanocrystals

Table 1. XRD spectral lines data of $\beta-\mathrm{NaGdF}_{4}$ nanocrystals

\begin{tabular}{|c|c|c|c|c|c|}
\hline S.No & $\mathbf{2 \theta}$ & $\begin{array}{c}\text { Height From } \\
\text { Base }\end{array}$ & $\begin{array}{c}\text { Width at half } \\
\text { height }\end{array}$ & d-spacing $(\mathbf{A})$ & $\begin{array}{c}\text { Thickness “t”" } \\
(\mathbf{n m})\end{array}$ \\
\hline 1 & 17 & 4.07 & 1.67 & 5.27 & 4.98 \\
\hline 2 & 30 & 15.66 & 1.24 & 3.00 & 6.87 \\
\hline 3 & 43 & 7.81 & 1.22 & 2.12 & 7.22 \\
\hline 4 & 52 & 8.71 & 1.11 & 1.74 & 8.23 \\
\hline
\end{tabular}

Here in Table 1, the 20, height of the peak from the base, width of the peak at half height, $d$-spacing (Calculated through Bragg's equation) and their respective thickness (calculated through Scherer's equation) are given. From Table one can easily observe that $2 \theta$ values for major reflections ranges from $17^{\circ}$ to $52^{\circ}$. Using the Bragg's equation, the $\mathrm{d}$-spacing in $\AA$ was calculated where it ranges from $1.74 \AA$ to a maximum of $5.27 \AA$. The thickness of the crystal lattice was calculated by Scherer's equation. The results indicate that crystal thickness ranges from 4.98 to $8.23 \mathrm{~nm}$.

From figure 5, X-ray diffraction spectrum for the sample $\beta$ - $\mathrm{NaGdF}_{4}: \mathrm{Yb} / \mathrm{Er}$ core may be observed. Well defined peaks indicate the presence of some repeated units in the sample which suggests that the sample $\beta-\mathrm{NaGdF}_{4}: \mathrm{Yb} / \mathrm{Er}$ is crystalline in nature. In Table 2, some well resolved reflections are summarized where $2 \theta$ values ranges from $17^{\circ}$ to $56^{\circ}$ which through Bragg's equation suggests that the spacing between the two reflections faces ranges from $1.64 \AA$ to $5.22 \AA$. Applying Scherer's equation, it was revealed that thickness of the crystals present in sample of $\beta-\mathrm{NaGdF}_{4}: \mathrm{Yb} / \mathrm{Er}$ core nanocrystals ranges from $0.94 \mathrm{~nm}$ to $8.66 \mathrm{~nm}$.

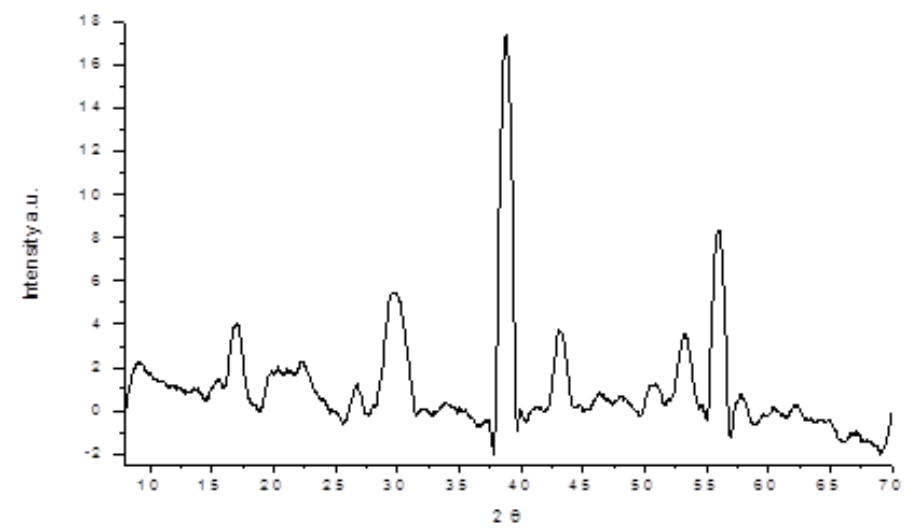

Figure 5. X-ray Diffraction (XRD) measurement of core $\left(\beta-\mathrm{NaGdF}_{4}: \mathrm{Yb} / \mathrm{Er}\right)$ nanocrystals
Table 2 XRD spectral lines data of $\beta-\mathrm{NaGdF}_{4}: \mathrm{Yb} / \mathrm{Er}$ nanocrystal.

\begin{tabular}{|c|c|c|c|c|c|}
\hline S.No & $\mathbf{2 \theta}$ & $\begin{array}{c}\text { Height From } \\
\text { Base }\end{array}$ & $\begin{array}{c}\text { Width at half } \\
\text { height }\end{array}$ & d-spacing $(\mathbf{A})$ & $\begin{array}{c}\text { Thickness “t” } \\
(\mathbf{n m})\end{array}$ \\
\hline 1 & 17 & 1.84 & 8.82 & 5.22 & 0.94 \\
\hline 2 & 30 & 2.62 & 1.88 & 3.01 & 4.51 \\
\hline 3 & 39 & 7.49 & 1.08 & 2.32 & 8.01 \\
\hline 4 & 43 & 1.72 & 1.12 & 2.10 & 7.86 \\
\hline 5 & 53 & 1.66 & 1.22 & 1.72 & 7.50 \\
\hline 6 & 56 & 3.63 & 1.07 & 1.64 & 8.66 \\
\hline
\end{tabular}

The X-ray diffraction spectrum for the sample of $\beta$-NaGdF4:Yb/Er@ $\beta$ NaGdF4:Nd core-shell is given in figure 6 .

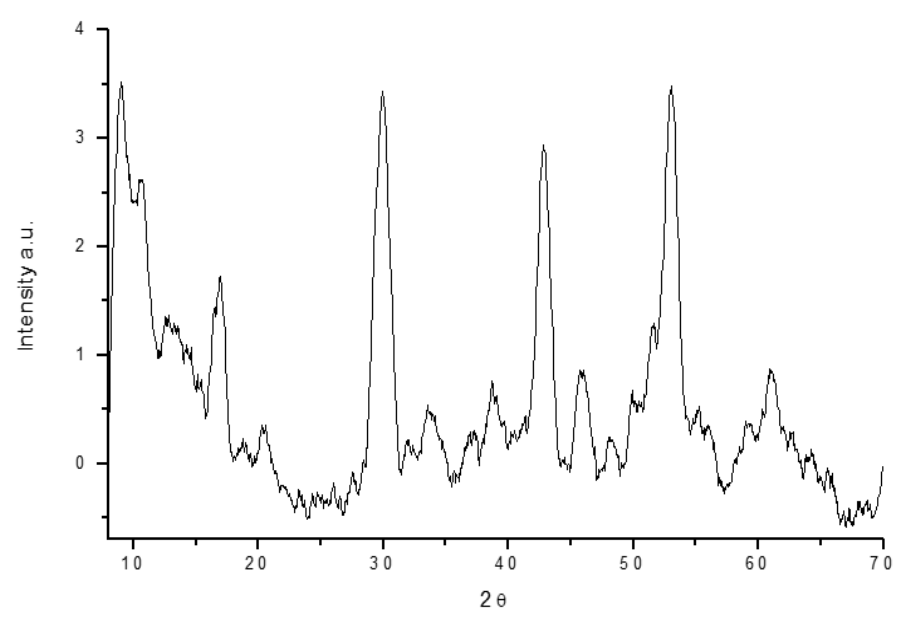

Figure 6. XRD pattern of $\beta-\mathrm{NaGdF}_{4}: \mathrm{Yb} / \mathrm{Er} @ \beta-\mathrm{NaGdF}_{4}: \mathrm{Nd}$ core-shell nanocrystals.

Well defined peaks indicate regular patterns in the core shell which are due to the presence of $\beta-\mathrm{NaGdF}_{4}: \mathrm{Yb} / \mathrm{Er} @ \beta-\mathrm{NaGdF}_{4}: \mathrm{Nd}$ crystals. The spectral lines are summarized in Table 3. Values in Table are generated in Origin ${ }^{\circledR}$ 8.0, whereas thickness " $t$ " and "d-spacing" of diffraction peaks are calculated using MS-Excel 2007. In Table 3 , the $2 \theta$ values range from $17^{\circ}$ to $56^{\circ}$. Applying Bragg's equation the d-spacing between different faces is calculated which ranges from $1.54 \AA$ to $9.81 \AA$.

Table 3. XRD spectral lines data of of $\beta-\mathrm{NaGdF}_{4}: \mathrm{Yb} / \mathrm{Er} @ \beta-\mathrm{NaGdF}_{4}: \mathrm{Nd}$ coreshell nanocrystals.

\begin{tabular}{|c|c|c|c|c|c|}
\hline S.No & $\mathbf{2 \theta}$ & $\begin{array}{c}\text { Height From } \\
\text { Base }\end{array}$ & $\begin{array}{c}\text { Width at half } \\
\text { height }\end{array}$ & d-spacing (̊̊) & $\begin{array}{c}\text { Thickness “t”" } \\
(\mathbf{n m})\end{array}$ \\
\hline 1 & 09 & 1.10 & 1.93 & 9.81 & 4.26 \\
\hline 2 & 17 & 0.83 & 1.27 & 5.21 & 6.53 \\
\hline 3 & 30 & 1.56 & 1.42 & 2.98 & 5.98 \\
\hline 4 & 39 & 0.33 & 1.08 & 2.31 & 8.06 \\
\hline 5 & 43 & 1.42 & 1.23 & 2.10 & 7.17 \\
\hline 6 & 46 & 0.02 & 0.56 & 1.97 & 15.92 \\
\hline 7 & 52 & 0.11 & 1.92 & 1.76 & 4.76 \\
\hline 8 & 53 & 1.72 & 1.36 & 1.72 & 6.74 \\
\hline 9 & 60 & 0.38 & 1.44 & 1.54 & 6.58 \\
\hline
\end{tabular}

These experimental values further reveal that the thickness of these crystalline structures is from $4.26 \mathrm{~nm}$ to $15.92 \mathrm{~nm}$. 


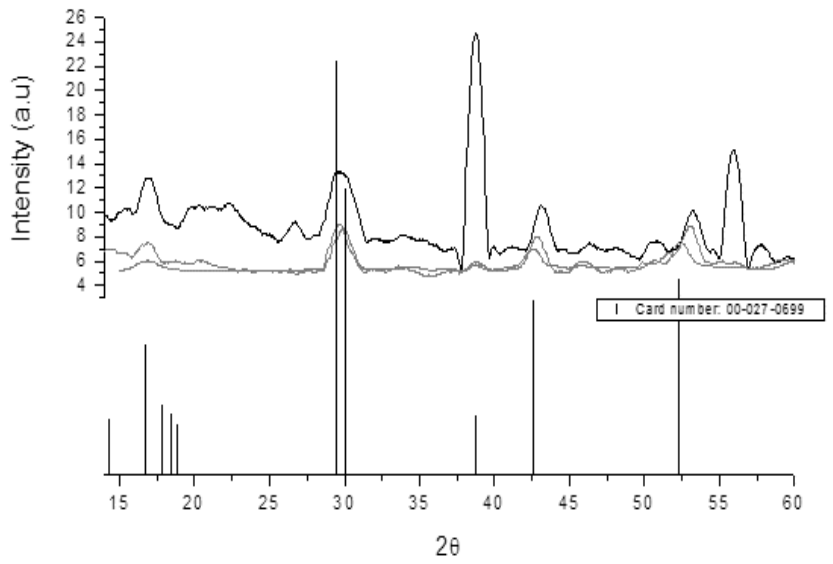

Figure 7. XRD spectra of standard reference pattern of $\beta-\mathrm{NaGdF}_{4}$ (red) (JCPDS 27-0699), core $\beta-\mathrm{NaGdF}_{4}: \mathrm{Yb} / \mathrm{Er}$ (black) and core-shell $\beta$ $\mathrm{NaGdF}_{4}: \mathrm{Yb} / \mathrm{Er} @ \beta-\mathrm{NaGdF}_{4}: \mathrm{Nd}$ (blue) nanocrystals

Form figure 7, it may be observed that the diffractogram of all crystals (core and core shell crystals) are alike. The positions of well-defined diffraction peaks are consistent with that of reference crystals of $\mathrm{NaGdF}_{4}$ in hexagonal structure (JCPDS 27-0699).

\section{FT-IR Studies}

Fourier transform infrared (FTIR) spectra of the prepared $\mathrm{NaGdF}_{4}$ (host), $\mathrm{NaGdF}_{4} / \mathrm{Yb} / \mathrm{Er}$ (Core) and $\mathrm{NaGdF}_{4} / \mathrm{Yb} / \mathrm{Er} @ \mathrm{NaGdF}_{4} / \mathrm{Nd}$ (Core@ shell) nanocrystals are shown in figure 8, where peaks at 2927 and $2852 \mathrm{~cm}^{-1}$ indicate the characteristic stretching of $-\mathrm{CH}_{2}$ group of the oleic acid attached to the $\mathrm{NaGdF}_{4}$ nanocrystals. Peaks at $1565 \mathrm{~cm}^{-1}$ and $1464 \mathrm{~cm}^{-1}$ are attributed to $-\mathrm{COOH}$ stretching, whereas peaks at $3416 \mathrm{~cm}^{-1}$ and $1551 \mathrm{~cm}^{-1}$ are to assigned to $-\mathrm{OH}$ and $\mathrm{C}=\mathrm{O}$ stretching respectively. Furthermore, two peaks appeared at $1402 \mathrm{~cm}^{-1}$ and $1093 \mathrm{~cm}^{-1}$ indicate that $-\mathrm{OH}, \mathrm{C}-\mathrm{OH}$, and $-\mathrm{COOH}$ groups are present at the surface of the synthesized nanocrystals.

The FTIR spectrum of the nanocrystals was similar to the spectra given in the literature $[32,33]$ where the presence of $-\mathrm{OH}$ and $-\mathrm{COOH}$ indicate that some hydrophilic character may be one of the prominent properties of the synthesized nanocrystals making them favorable for applications in the field of biomedicines and alike.

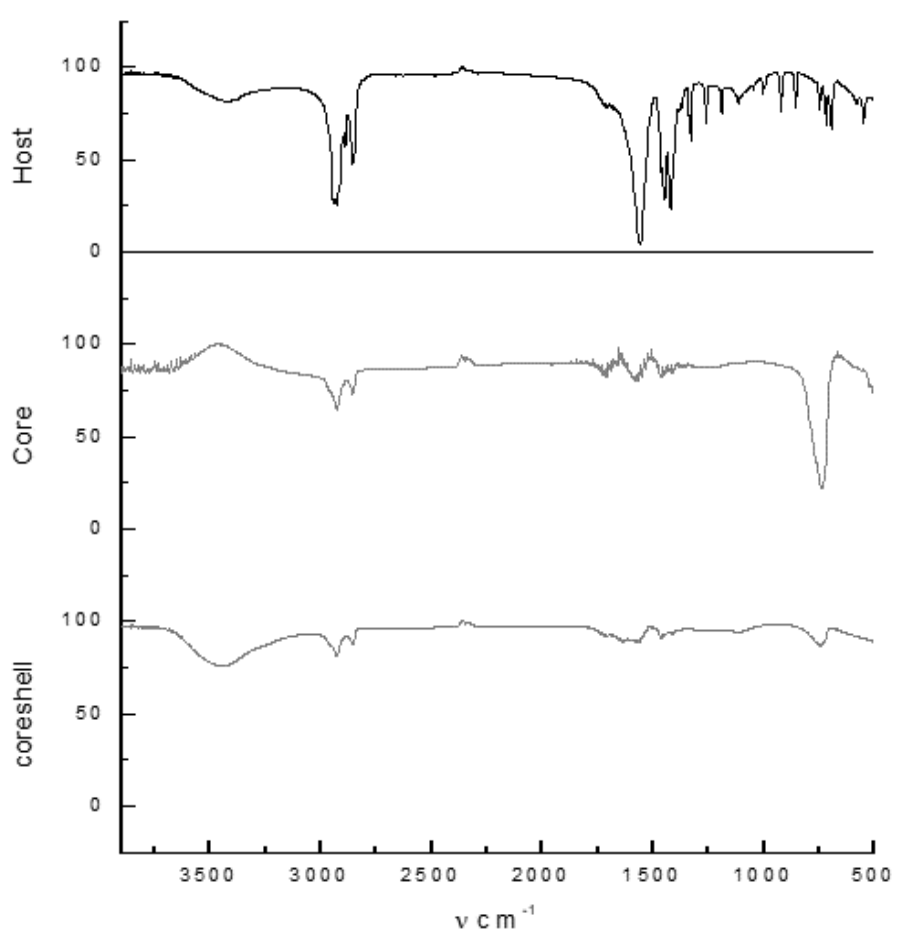

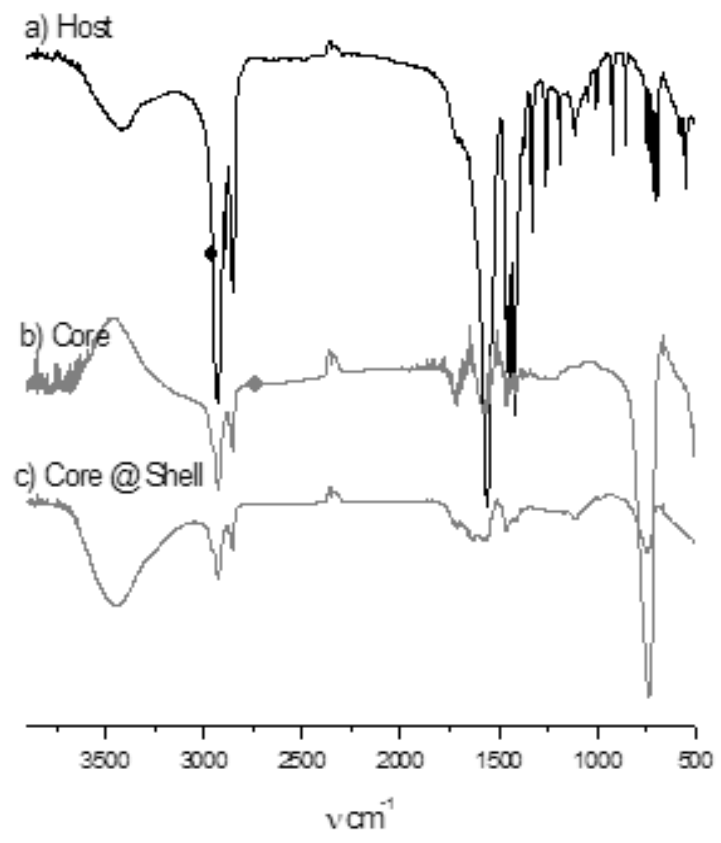

Figure 8. (a) Host: $\mathrm{NaGdF}_{4}$ b) Core: $\mathrm{NaGdF}_{4} / \mathrm{Yb} / \mathrm{Er}$ c) Core@ shell: $\mathrm{NaGdF}_{4} / \mathrm{Yb} / \mathrm{Er} @ \mathrm{NaGdF}_{4} / \mathrm{Nd}$

\section{CONCLUSIONS}

This work reports the synthesis of $\beta-\mathrm{NaGdF}_{4}$ nanocrystals. These nanocrystals were doped with $\mathrm{Yb}$ and $\mathrm{Er}$ to produce core nanocrystals $\left(\beta-\mathrm{NaGdF}_{4}: \mathrm{Yb} / \mathrm{Er}\right)$. A layer of $\beta-\mathrm{NaGdF}_{4}: \mathrm{Nd}$ was coated as shell over the core nanocrystals to produce core-shell nanocrystals as $\beta$ - $\mathrm{NaGdF}_{4}: \mathrm{Yb} / \mathrm{Er} @ \beta-\mathrm{NaGdF}_{4}: \mathrm{Yb} / \mathrm{Er} . \quad \beta-\mathrm{NaGdF}_{4}$ nanomaterials doped with $\mathrm{Yb}$ and $\mathrm{Er}$ (green and red emission) are well known up-converting materials. Therefore, core-shell nanocrystals prepared in this work can be investigated as up-converting materials. They are expected to be useful for X-ray tomography because gadolinium is a heavy element, capable of strongly absorbing X-rays. Gadolinium-based nanomaterials are also applied as MRI contrast agents because Gd increases water protons relaxation rate. Thus, these nanocrystals are likely to be suitable contrast agents for photoluminescence, MRI and X-ray tomography. However, further research is needed for their in vivo investigations.

\section{CONFLICTS OF INTEREST}

The authors declare no conflicts of interest.

\section{ACKNOWLEDGMENTS}

The authors are thankful to Brazilian Foundation Agency (CNPq) for providing financial support to execute this project (400662/2013-2).

\section{REFERENCES}

1. A. K. Buck, S. Nekolla, S. Ziegler, A. Beer, B. J. Krause, K. Herrmann, K. Scheidhauer, H.-J. Wester, E. J. Rummeny M. J. J. N. M. Schwaiger, J. Nucl. Med. 49, 1305 (2008)

2. A. Galperin, D. Margel, J. Baniel, G. Dank, H. Biton S. Margel, Biomaterials 28, 4461 (2007)

3. O. M. Merkel, D. Librizzi, A. Pfestroff, T. Schurrat, M. Béhé T. Kissel, Bioconj. Chem. 20, 174 (2008)

4. B. J. Pichler, H. F. Wehrl M. S. J. J. o. N. M. Judenhofer, J. Nucl. Mater. 49, 5S (2008)

5. B. J. Pichler, A. Kolb, T. Nägele H.-P. Schlemmer, J. Nucl. Med. 51, 333 (2010)

6. R. Bar-Shalom, N. Yefremov, L. Guralnik, D. Gaitini, A. Frenkel, A. Kuten, H. Altman, Z. Keidar O. Israel, J. Nucl. Med. 44, 1200 (2003)

7. A. Dirksen, S. Langereis, B. F. de Waal, M. H. van Genderen, T. M. Hackeng E. Meijer, Chem. Commun. 2811 (2005). 
8. J.-L. Bridot, A.-C. Faure, S. Laurent, C. Riviere, C. Billotey, B. Hiba, M. Janier, V. Josserand, J.-L. Coll L. Vander Elst, J. Am. Chem. Soc. 129, 5076 (2007)

9. J. Liu, W. Bu, S. Zhang, F. Chen, H. Xing, L. Pan, L. Zhou, W. Peng J. Shi, Chem. A Eur. J. 18, 2335 (2012)

10. S. Adams, R. P. Baum, T. Stuckensen, K. Bitter G. Hör, Eur. J. Nucl. Med. 25,1255 (1998)

11. H. U. Rashid, K. Yu J. Zhou, J. Struct. Chem. 54, 223 (2013)

12. R. H. U., M. N. Umar, K. Khan, M. N. Anjum M. Yaseen, J. Struct. Chem. 55,910 (2014)

13. H. U. Rashid, K. Khan, M. Yaseen, W. Hassan M. N. UMAR, Rom. J. Chem. 59, 27 (2014)

14. F. Zhang, in Photon Upconversion Nanomaterials, Springer, 2015, pp. 187.

15. J. Cheon J.-H. Lee, Acc. Chem. Res. 41, 1630 (2008)

16. W. J. Mulder, A. W. Griffioen, G. J. Strijkers, D. P. Cormode, K. Nicolay Z. A. Fayad, Nanomedicine 2, 307 (2007)

17. C. Bremer R. Weissleder, Acad. Radiol. 8, 15 (2001)

18. T. Persigehl, W. Heindel C. Bremer, Abdom. Imaging 30, 343 (2005)

19. D. Sosnovik R. Weissleder, in Imaging in Drug Discovery and Early Clinical Trials, Springer, 2005, pp. 83.

20. F. Liu, X. He, L. Liu, H. You, H. Zhang Z. Wang, Biomaterials 34, 5218 (2013)
21. D. K. Chatterjee, M. K. Gnanasammandhan Y. Zhang, Small 6, 2781 (2010)

22. J. Zhou, X. Zhu, M. Chen, Y. Sun F. Li, Biomaterials 33, 6201 (2012)

23. C. Wang, H. Tao, L. Cheng Z. Liu, Biomaterials 32, 6145 (2011)

24. K. W. Krämer, D. Biner, G. Frei, H. U. Güdel, M. P. Hehlen S. R. Lüthi, Chem. Mater. 16, 1244 (2004)

25. M. He, P. Huang, C. Zhang, H. Hu, C. Bao, G. Gao, R. He D. Cui, Adv. Funct. Mater. 21, 4470 (2011)

26. S. Zeng, M.-K. Tsang, C.-F. Chan, K.-L. Wong J. Hao, Biomaterials 33, 9232 (2012)

27. Y. F. Wang, L. D. Sun, J. W. Xiao, W. Feng, J. C. Zhou, J. Shen C. H. Yan, Chem. A Eur. J. 18, 5558 (2012)

28. S. Dühnen M. Haase, Chem. Mater. 27, 8375 (2015)

29. A. Mondry K. J. A. P. P.-S. A. G. P. Bukietynska, Acta Physica PolonicaSeries A General Physics 90, 233 (1996)

30. J. Tian, X. Zeng, X. Xie, S. Han, O.-W. Liew, Y.-T. Chen, L. Wang X. Liu, J. Am. Chem. Soc. 137, 6550 (2015)

31. S. Zheng, W. Chen, D. Tan, J. Zhou, Q. Guo, W. Jiang, C. Xu, X. Liu J. Qiu, Nanoscale 6, 5675 (2014)

32. X. Sun Y. Li, Angew. Chem. 116, 607 (2004)

33. X. Liu, L. Wang, Z. Wang Z. Li, J. Mater. Res. 26, 82 (2011) 